DOI: $10.15193 /$ zntj/2021/126/367

\author{
BARTOSZ ZIMNICKI, SYLWIA MILDNER-SZKUDLARZ, \\ RADOSŁAW SPYCHAJ, MATEUSZ GUTSCHE
}

\title{
ZASTOSOWANIE METODY SRC (SOLVENT RETENTION CAPACITY) DO OKREŚLANIA PRZYDATNOŚCI TECHNOLOGICZNEJ MĄKI PSZENNEJ
}

\author{
Streszczenie
}

Celem opracowania było przedstawienie syntetycznej wiedzy o metodzie SRC (ang. Solvent Retention Capacity), z uwzględnianiem jej historii, dostępnych wariantów aparaturowych, zasad postępowania podczas wykonania oznaczenia oraz kierunków zastosowania.

Metoda SRC została opracowana w połowie XX w. do oceny jakości mąki z pszenicy miękkiej (ang. soft wheat) pochodzącej z Ameryki Północnej. W publikacjach z XXI w. przedstawiono dane wskazujące na przydatność i szeroki zakres stosowania metody SRC także do oceny jakości mąki z klasycznej europejskiej pszenicy zwyczajnej (Triticum aestivum) oraz z mąk uzyskanych z innych zbóż, jak: jęczmień, owies, pszenżyto i żyto. Metoda SRC jest testem solwatacyjnym bazującym na ocenie zdolności pęcznienia składników mąki w środowisku wybranych roztworów. Zastosowanie w omawianej metodzie nie jednego, lecz trzech roztworów (rozcieńczonego wodnego roztworu węglanu sodu, stężonego wodnego roztworu sacharozy i rozcieńczonego wodnego roztworu kwasu mlekowego) oraz wody jest kluczowe dla oceny możliwości zastosowania mąki w poszczególnych procesach technologicznych. Wykorzystanie powinowactwa tych roztworów do głównych funkcjonalnych polimerów mąki pszennej, jakimi są białka glutenowe, skrobia uszkodzona oraz pentozany, pozwala na określnie ich wpływu na właściwości mąki oraz na jakość produktów końcowych w technologii piekarskiej i ciastkarskiej. Metoda SRC umożliwia ocenę właściwości mąki, dokonanie doboru odmian czy metod uprawy, co ma istotne znaczenie w młynarstwie oraz w zakładach produkcyjnych, w których mąka pszenna jest podstawowym surowcem.

Słowa kluczowe: Solvent Retention Capacity (SRC), pszenica miękka, mąka pszenna, mąka waflowa, właściwości technologiczne

\footnotetext{
Mgr inż. B. Zimnicki, Katedra Technologii Żywności Pochodzenia Roślinnego, Wydz. Nauk o Żywności i Żywieniu, Uniwersytet Przyrodniczy w Poznaniu, ul. Wojska Polskiego 28, 60-637 Poznań, GoodMills Polska, ul. Serbska 4, 61-596 Poznań, dr hab. S. Mildner-Szkudlarz, prof. UPP, Katedra Technologii Żywności Pochodzenia Roślinnego, Wydz. Nauk o Żywności i Żywieniu, Uniwersytet Przyrodniczy w Poznaniu, ul. Wojska Polskiego 28, 60-637 Poznań, dr inż. R. Spychaj, Katedra Technologii Fermentacji i Zbóż, Wydz. Biotechnologii i Nauk o Żywności, Uniwersytet Przyrodniczy we Wrocławiu, ul. Chetmońskiego 37, 51-630 Wrocław, dr inż. M. Gutsche, GoodMills Polska, ul. Serbska 4, 61-596 Poznań. Kontakt: sylwia.mildner-szkudlarz@up.poznan.pl
} 


\section{Wprowadzenie}

Pszenica jest jednym z najstarszych surowców służących do produkcji żywności. Uprawiana była już w starożytności, a w czasach współczesnych zajmuje trzecie miejsce w światowej produkcji zbóż. Wraz z postępem techniki i rozwojem wiedzy na temat pszenicy wprowadzano zmiany w uprawie, selekcjonowanie odmian i coraz szersze wykorzystanie jej przetworów. Pod wpływem czynników ekonomicznych, a także w związku ze zmianami społeczno-kulturowymi, jakie miały miejsce w ostatnich latach, nastąpił wyraźny wzrost skali produkcji tego zboża oraz bardzo duża koncentracja zakładów przetwarzających mąkę pszenną.

Jakość mąki jest wypadkową czynników genetycznych i agrotechnicznych oraz warunków procesu przemiału ziarna. Jakość uzyskiwanych produktów piekarskich zależy od jakości podstawowego surowca, jakim jest mąka, a także od doboru odpowiednich parametrów i przebiegu procesów technologicznych [18].

Za jakość mąki i jej przydatność do produkcji pieczywa odpowiedzialne są dwa układy: białkowo-proteolityczny oraz skrobiowo-amylolityczny. Wartość wypiekową mąki określa się m.in. testami pośrednimi, jak: oznaczanie ilości i jakości glutenu, liczba opadania oraz analizy reologiczne. W każdym procesie z użyciem mąki kluczowe znaczenie ma rozprowadzenie wody wśród składników tego surowca, a także zdolność do jej długotrwałego zatrzymywania [18]. Całkowita wodochłonność mąki pszennej zależy od zawartości pentozanów, skrobi, skrobi uszkodzonej oraz białek glutenowych (rys. 1). Pentozany, głównie arabinoksylany, są uważane za składniki mąki o największej zdolności zatrzymywania wody, charakteryzowanej wskaźnikiem WHC (ang. Water Hold Capacity) na poziomie $10 \mathrm{~g} \mathrm{H}_{2} \mathrm{O} / \mathrm{g}$ suchych arabinoksylanów. Skrobia natywna może zatrzymać tylko $0,3 \div 0,45 \mathrm{~g} \mathrm{H}_{2} \mathrm{O} / \mathrm{g}$ suchej skrobi, podczas gdy skrobia uszkodzona wiąże $1,5 \div 2,0 \mathrm{~g} \mathrm{H}_{2} \mathrm{O} / \mathrm{g}$ suchej skrobi uszkodzonej. Natomiast $1 \mathrm{~g}$ suchego glutenu pszennego jest w stanie zatrzymać ok. 2,8 g wody w stosunku do swojej masy, a ilości wody wiązane przez pozostałe białka uznaje się za nieistotne [18]. Rozprowadzenie wody wśród składników mąki jest równomierne, czego efekt końcowy stanowi wodochłonność mąki (rys. 2).

Mąka pszenna do celów piekarskich powinna charakteryzować się dużą wodochłonnością, mocnym glutenem oraz podwyższoną zawartością skrobi uszkodzonej i pentozanów. Odmienne wymagania stawia się produktom młynarskim używanym do produkcji innych produktów piekarskich, takich jak: ciastka, krakersy lub wafle. Mąka do produkcji ciastek powinna odznaczać się małą wodochłonnością oraz małymi zawartościami glutenu, skrobi uszkodzonej i pentozanów [18]. Z kolei mąka do produkcji wafli powinna zawierać mało białka i cechować się słabym glutenem [14]. Wydaje się jednak, że jest to pogląd znacznie uproszczony. Skrobia uszkodzona powstająca $\mathrm{w}$ procesie przemiału oraz arabinoksylany pochodzące $\mathrm{z}$ zewnętrznych części anatomicznych ziarna (warstwa aleuronowa i okrywa owocowo-nasienna) w znacznym 


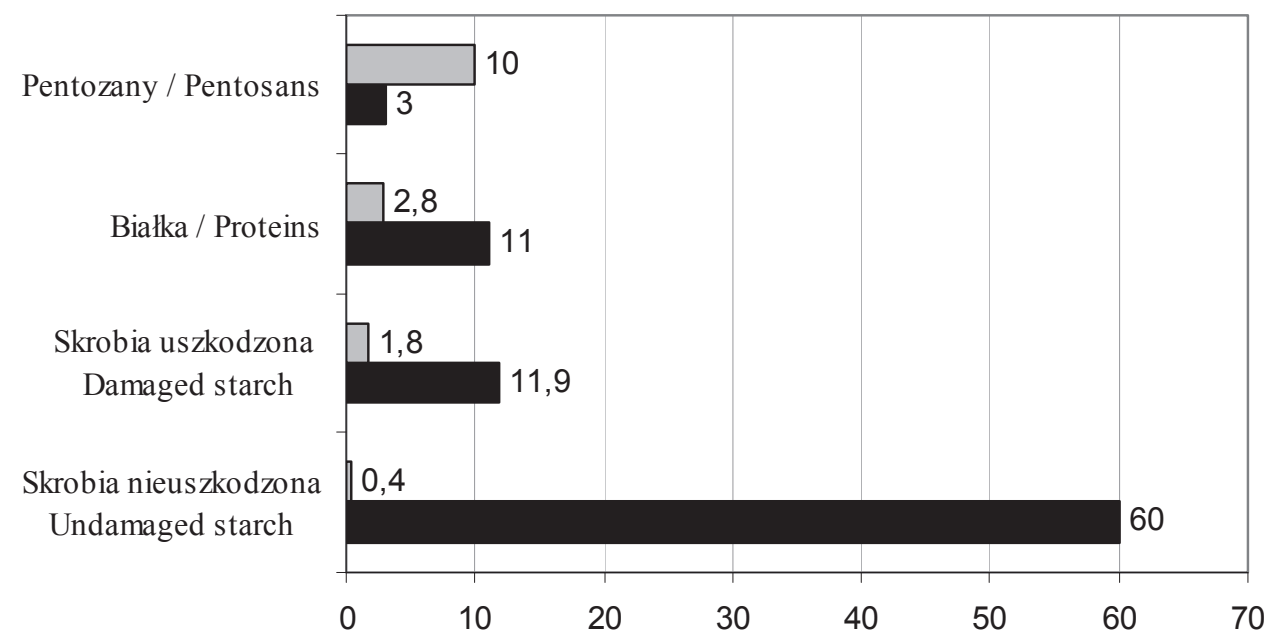

$\square$ Zdolność chłonięcia wody [g/1 g s.s.] / Water-holding capacity [g/1 g d.s.]

- Zawartość w mące / Content in flour [\%]

Rys. 1. Zawartość poszczególnych składników mąki pszennej i ich zdolność do zatrzymywania wody

Fig. 1. Content of individual components of wheat flour and their water absorption capacity Źródło / Source: opracowanie własne na podstawie [18] / the author's own study based on [18]

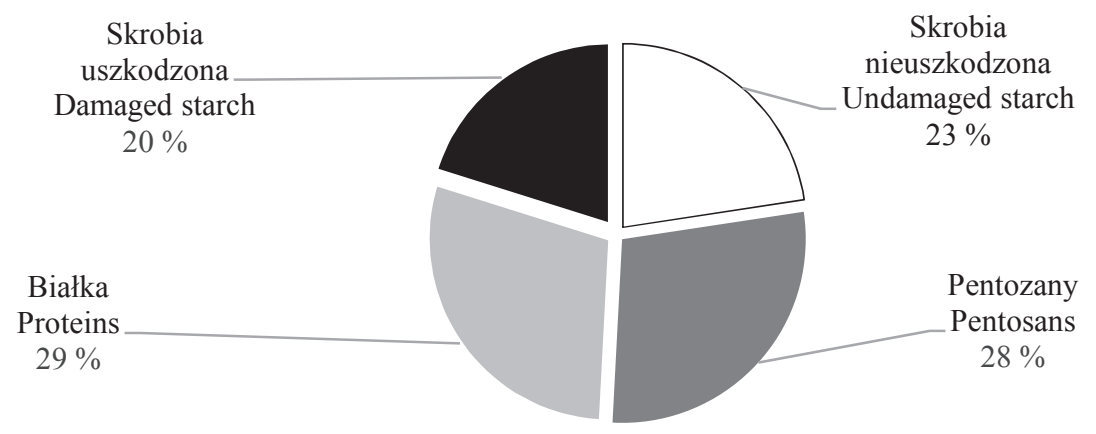

Rys. 2. Udział poszczególnych składników mąki pszennej w tworzeniu ogólnej wodochłonności

Fig. 2. Share of individual components of wheat flour in forming overall water absorption Źródło / Source: opracowanie własne na podstawie [18] / the author's own study based on [18]

stopniu zwiększają zdolność chłonięcia wody, co jest niepożądane w przypadku mąki przeznaczonej do produkcji ciastek, krakersów i wafli o dobrej jakości. Zwiększona zdolność chłonięcia wody przez mąkę niekorzystnie wpływa na procesy formowania oraz rozwoju ciasta i wymaga zastosowania większej ilości wody. Powoduje to wydłu- 
żenie czasu wypieku w wyższej temperaturze, a przez to wzrost kosztów produkcji. W przypadku produkcji wafli zwiększenie ilości wody niezbędnej do przygotowania ciasta waflowego o odpowiedniej konsystencji nie tylko obniża jakość wyrobu końcowego, ale może również uniemożliwić realizację procesu produkcyjnego [22].

Do badania przydatności technologicznej mąki wprowadzono metodę Solvent Retention Capacity (SRC), mało znaną w Polsce, ale szeroko rozpowszechnioną w innych krajach, zwłaszcza w Stanach Zjednoczonych [19].

Celem opracowania było przedstawienie syntetycznej wiedzy o metodzie SRC, z uwzględnianiem jej historii, dostępnych wariantów aparaturowych, zasad postępowania podczas wykonywania oznaczenia oraz kierunków zastosowania.

\section{Historia metody SRC}

Już w 1946 r. Finney i Yamazaki stwierdzili wysoką korelację pomiędzy wartościami zdolności zatrzymywania wody w środowisku kwaśnym (ang. acid-water retention capacity) a objętością bochenków chleba. W trakcie dalszych badań autorzy oznaczyli w kruchych ciastkach zdolność zatrzymywania wody w środowisku zasadowym (ang. alkaline water retention capacity) i wykazali wysoką korelację uzyskanych wyników ze średnicą wypiekanych ciastek. W 1953 r. metoda została zatwierdzona przez Amerykańskie Stowarzyszenie Chemików Zbożowych jako AACC 56-10.02. W metodzie tej używano $0,1 \mathrm{~N}$ roztworu wodorowęglanu sodu o $\mathrm{pH} 8$, dzięki czemu możliwe było określenie ilości wody związanej przez wszystkie funkcjonalne składniki mąki. Metoda nie pozwalała jednak na pełną ocenę jakości mąki. Nadal poszukiwano metody określania zdolności zatrzymywania wody przez poszczególne składniki mąki. Taką nowatorską metodę opracował i wdrożył Louis Slade z firmy Nabisco w późnych latach 80. XX w., a jej celem było badanie jakości mąki z tzw. pszenicy miękkiej ${ }^{1}$, jako surowca do produkcji ciastek i krakersów [18].

Metoda SRC określająca zdolność zatrzymywania roztworów została zatwierdzona w roku 2000 jako AACC 56-11.02 [23].

\section{Zasada oznaczania i interpretacja wyników SRC}

W metodzie SRC określa się zdolność mąk pszennych do absorbowania 5-procentowego roztworu węglanu sodu $\left(\mathrm{Na}_{2} \mathrm{CO}_{3} \mathrm{SRC}\right)$, 50-procentowego roztworu sacharozy (Suc SRC), 5-procentowego roztworu kwasu mlekowego (LA SRC) oraz wody demineralizowanej (Wa SRC). Wszystkie roztwory należy przechowywać nie dłużej niż 7 dni w temperaturze pokojowej, aby uzyskać wiarygodne wyniki. Dotyczy

\footnotetext{
${ }^{1}$ pszenica miękka (ang. soft wheat) określa grupę odmian pszenicy zwyczajnej (Triticum aestivum), które w stosunku do klasycznych odmian tej pszenicy wykazują odmienne cechy budowy i struktury ziarniaka. Odmienne są także właściwości technologiczne uzyskiwanych z niej przetworów.
} 
to zwłaszcza roztworu sacharozy oraz roztworu kwasu mlekowego ze względu na zachodzące w nich niekorzystne zmiany o charakterze mikrobiologicznym i chemicznym. Stężenie normalne roztworu kwasu mlekowego przechowywanego w temperaturze pokojowej wzrasta z 1,000 do 1,185 i ten wzrost postępuje przynajmniej przez miesiąc. Oznaczenie SRC wykonane z użyciem takiego roztworu kwasu mlekowego przyczynia się do wzrostu lepkości wodnej zawiesiny mąki i błędnej interpretacji uzyskanych wyników [18]. Temperatura roztworów ma także istotne znaczenie, ponieważ woda w środowisku nie występuje w postaci wolnych cząsteczek $\mathrm{H}_{2} \mathrm{O}$, lecz jest spolimeryzowana. Na przykład w temp. $4{ }^{\circ} \mathrm{C}$ występuje cząsteczka $\left[\mathrm{H}_{2} \mathrm{O}\right]_{12}$, w miarę podgrzewania następuje jej depolimeryzacja, a w temperaturze wrzenia zmienia się w parę - pojedynczą cząsteczkę $\mathrm{H}_{2} \mathrm{O}$. Jeżeli temperatura roztworu nie jest odpowiednia, to woda spolimeryzowana w innym stopniu, ze względu na swoją fizyczną wielkość, może nie wziąć udziału w reakcji w takim samym stopniu, jakby to miało miejsce we właściwej temperaturze [13].

W metodzie SRC zdolności hydratacyjne mąki oznacza się wagowo, stąd do $5 \pm$ 0,05 g próbki umieszczonej w probówce wirówkowej ze stożkowym dnem dodaje się $25 \pm 0,05$ g roztworu i dokładnie miesza uzyskaną zawiesinę. Reakcję uwodnienia prowadzi się przez $20 \mathrm{~min}$ (wytrząsając co $5 \mathrm{~min}$ ). Powstałą zawiesinę wiruje się przez 15 min przy 1000 g. Po odwirowaniu odlewa się supernatant, a probówkę stawia do góry dnem na 10 min w celu osuszenia. Po zważeniu probówki oblicza się masę osadu, a następnie dla zastosowanego roztworu oblicza się wartość SRC z równania [11]:

$$
\mathrm{SRC}[\%]=\left[\frac{\text { masa osadu }}{\text { masa próbki }}-1\right] \times\left[\frac{86}{100-\text { wilgotność próbki }}\right] \times 100
$$

Kweon i wsp. [18] uważają, że jeżeli doświadczona osoba wykona analizę tej samej zhomogenizowanej próbki w 10 powtórzeniach, rozrzut wyników w przypadku poszczególnych roztworów powinien zawierać się w zakresach: Wa SRC $- \pm 0,5 \%$, $\mathrm{Na}_{2} \mathrm{CO}_{3} \mathrm{SRC}- \pm 0,5 \%$, Suc SRC $- \pm 1 \%$, LA SRC $- \pm 1 \%$. Z tego powodu wyniki podaje się z dokładnością nie większą niż 1 miejsce dziesiętne $(0,1 \%)$. Również Gaines [9], po przeprowadzeniu testów porównawczych w 9 laboratoriach, zauważa, że uzyskane wyniki charakteryzują się niskimi współczynnikami zmienności. Zaobserwował, że zmienność wyników jest zazwyczaj wyższa pomiędzy laboratoriami niż wewnątrz jednego laboratorium.

Należy podkreślić, że w przeciwieństwie do testów reologicznych wyniki SRC nie zależą od właściwości kinetycznych tworzącego się ciasta, gdyż analiza jest prowadzona w około pięciokrotnym nadmiarze roztworu w stosunku do ilości mąki.

Wyniki testu SRC dostarczają cennych informacji na temat cech jakościowych badanych mąk. Wchłanianie wody uzależnione jest od ilości i kombinacji wszystkich składników mąki. Zdolność do retencji roztworu $\mathrm{Na}_{2} \mathrm{CO}_{3}$ zależy od różnic w strukturze 
bielma oraz twardości ziarna. Mąka uzyskana z przemiału ziarna twardych odmian pszenicy charakteryzuje się większym stopień uszkodzenia skrobi oraz wyższą zdolnością do retencji roztworu $\mathrm{Na}_{2} \mathrm{CO}_{3}$. Im większy stopień uszkodzenia ziaren skrobi, tym większa ich podatność na hydrolizę enzymatyczną. Z kolei zdolność mąki do wchłaniania roztworu sacharozy charakteryzuje ilość i jakość pentozanów, a zdolność mąki do retencji roztworu kwasu mlekowego określa ilość i jakość białek tworzących gluten. Zawartość białek oraz pentozanów jest cechą charakterystyczną dla jakości pszenicy i może być w pewnym zakresie regulowana poprzez dobór mąk pasażowych, natomiast stopień uszkodzenia skrobi jest parametrem, który może być kształtowany w procesie przemiału [18].

Jak podaje Gaines [9], mąka charakteryzująca się wartościami: Wa SRC $\leq 51 \%, \mathrm{Na}_{2} \mathrm{CO}_{3} \mathrm{SRC}-\leq 64 \%$, Suc SRC $-\leq 89 \%$ i LA SRC $-\geq 87 \%$ umożliwia uzyskanie ciastek o wysokiej jakości, natomiast mąka o wartościach testu SRC: Wa SRC $-\leq 57 \%, \mathrm{Na}_{2} \mathrm{CO}_{3} \mathrm{SRC}-\leq 72 \%$, Suc SRC $-\leq 96 \%$ i LA SRC $-\geq 100 \%$ jest odpowiednia do produkcji ciast biszkoptowych.

Można wnioskować, że wyniki oznaczania SRC są determinowane przez jakość zastosowanego surowca oraz charakterystykę linii przemiałowej. Doświadczenia z pracy podczas przemysłowej produkcji mąk pszennych wskazują, że charakterystykę mąk pszennych w zakresie parametrów SRC można kształtować poprzez przygotowanie odpowiedniej mieszanki pszenicy, ustawienie linii przemiałowej oraz selekcjonowanie mąk pasażowych. Prowadząc badania należy mieć na uwadze, że granulki skrobi obecne w pszenicy zwyczajnej w poszczególnych odmianach lub partiach, zwłaszcza z podziałem na te o miękkim lub twardym bielmie (mączyste, szkliste), mają inną podatność na uszkodzenia podczas procesu przemiału. W trakcie przemiału pszenic o miękkim bielmie z luźniejszą strukturą większa ilość mąki jest uzyskiwana już w początkowych pasażach, a sam proces przemiału powinien być prowadzony w łagodniejszych warunkach przemiału właściwego. Dzięki temu składniki zawarte w bielmie nie podlegają takiemu uszkodzeniu, jak ma to miejsce podczas przemiału pszenicy zwyczajnej o bielmie twardym (szklistym), które jest bardziej zwarte i wydobycie frakcji mącznych odbywa się $w$ dalszych pasażach i wymaga intensywniejszego przemiału właściwego [7].

\section{Rodzaje aparatury stosowanej do oznaczenia SRC}

Pierwotna metoda, poza procesem odwirowania, w całości składała się z operacji manualnych, co mocno angażowało osobę wykonującą oznaczenie, a podczas wykonywania analiz przez osoby o różnym stopniu doświadczenia znacząco wpływało na uzyskiwane wyniki. Oczekiwano, że zautomatyzowanie metody pozwoliłoby na zastosowanie jej w laboratoriach przyzakładowych, odciążając personel oraz zwiększając powtarzalność i odtwarzalność wyników. Po 25 latach od opracowania metody SRC 
niemalże w tym samym czasie na rynku pojawiły się dwa urządzenia: w pełni automatyczny aparat CHOPIN-SRC, opracowany we współpracy z autorem metody oraz półautomatyczny zestaw do oznaczania SRC oferowany przez firmę Perten Instruments AB (Szwecja). W rozwiązaniu Chopin Technologies (Francja) manualnie odbywają się tylko etapy ważenia próbek oraz przygotowania odpowiedniej ilości roztworów i umieszczenie strzykawek z roztworami w urządzeniu. Po naważeniu próbek (na wadze połączonej z urządzeniem) i umieszczeniu ich we wnętrzu urządzenia, automatycznie w odpowiednich okresach czasowych wykonywane są czynności: dozowania roztworów, mieszania, wytrząsania, wirowania oraz zlewania i odciekania supernatantów. Po ręcznym umieszczeniu próbki na wadze wbudowanej w urządzenie obliczenie i wygenerowanie wyników następuje automatycznie. Badanie 12 próbek mąki w 12 laboratoriach z wykorzystaniem urządzenia Chopin-SRC potwierdziło wysoką powtarzalność i odtwarzalność uzyskiwanych wyników [5].

Zestaw opracowany przez Perten Instruments AB (Szwecja) wymaga większego zaangażowania personelu. Czynności wykonywane przez operatora to: ważenie próbek i roztworów, dodawanie roztworów do probówek, wstępne wymieszanie oraz umieszczanie probówek w poszczególnych urządzeniach (Shakematic, wytrząsarki i wirówka) pomiędzy kolejnymi etapami analizy, a także obliczenie wyniku.

Bettge i wsp. [3] do wczesnej oceny jakości odmian pszenicy zastosowali różne warianty metody SRC. Analizy wykonano z zastosowaniem oryginalnej manualnej metody, a także jej modyfikacji w zakresie zmniejszenia wielkości próbki (mąka - $1 \mathrm{~g}$, śruta całoziarnowa - 0,2 g) lub zastąpienia ręcznego wytrząsania przez zastosowanie wytrząsarki (zgodnej z AACC 56-61 A - oznaczanie sedymentacji SDS) lub rotatora. Zaobserwowano minimalną zmienność wyników pomiędzy ręcznym i automatycznym układem mieszania, a pomiędzy zastosowanymi metodami uzyskano istotne współczynniki korelacji w zakresie $0,69 \div 0,86$. Ponadto dowiedziono, że zmniejszenie wielkości próbek umożliwiło ich rozsortowanie na te $\mathrm{z}$ wysokimi i z niskimi wartościami SRC. Jeśli jednak dostępna jest wystarczająca ilość surowca, powinno się stosować wielkość próbki opisaną w metodyce, aby uzyskać dokładną ocenę badanego materiatu.

Kweon i wsp. [18] zwracają uwagę na wskaźnik GPI (ang. Gluten Performance Index) zdefiniowany równaniem:

$$
\mathrm{GPI}=\frac{\mathrm{LA} \mathrm{SRC}}{\mathrm{Na}_{2} \mathrm{CO}_{3} \mathrm{SRC}+\mathrm{Suc} \mathrm{SRC}}
$$

Może on być dobrym wskaźnikiem do przewidywania ogólnej jakości białek glutenowych zawartych w mące. Wymienieni autorzy zaobserwowali, że wartość GPI zwiększa się wraz ze wzrostem uzysku mąki podczas przemiału (uzysk mąki zdefiniowano jako iloraz masy uzyskanej mąki do masy zmielonej pszenicy) aż do poziomu ok. 
1/3 tego uzysku. Dalsze zwiększanie uzysku mąki powoduje drastyczne obniżanie wartości GPI, gdyż zmniejsza się LA SRC i wzrasta ilość skrobi uszkodzonej mierzonej jako $\mathrm{Na}_{2} \mathrm{CO}_{3}$ SRC. Kweon i wsp. [17] przebadali 28 odmian pszenicy. Stwierdzili, że wskaźnik GPI wahał się w przedziale $0,434 \div 0,730$. Autorzy wykazali istotną korelację $(\mathrm{r}=0,63)$ pomiędzy GPI a parametrami jakościowymi krakersów i uznali, że najlepsze efekty uzyskuje się, gdy wskaźnik GPI $<0,52$.

\section{Możliwości zastosowania metody SRC}

Oprócz oceny funkcjonalności mąk pszennych uzyskanych z przemiału amerykańskich pszenic miękkich i twardych przeznaczonych do produkcji ciastek oraz krakersów, metodę SRC zastosowano także do badania jakości mąk wykorzystywanych do innych celów i na różnych etapach produkcji zbożowo-młynarskiej. Metoda była wdrażana na poziomie hodowli zbóż, młynarstwa i w przemyśle piekarskim, a także szeroko stosowali ją naukowcy. Metodą SRC prowadzono badania jakości ziarna pszenicy i mąk pszennych w różnych krajach i na różnych kontynentach, m.in. w Europie [6] - Czechy [25] i Polska [1], w Ameryce Południowej i Północnej - Argentyna [24], Meksyk [10] czy Azji - Indie [15]. Wnioski z badań prowadzonych w zakresie oceny jakości mąk przeznaczonych na cele piekarskie nie były jednoznaczne. Achremowicz i wsp. [1] nie stwierdzili istotnej korelacji pomiędzy wskaźnikami metody SRC a wynikami technologicznej oceny mąk pszennych i jakości chleba. Jedynie objętość pieczywa była wysoko istotnie $(\mathrm{p}=0,01)$ ujemnie skorelowana z Wa SRC $(r=-0,658)$ i przeciętnie $(\mathrm{p}=0,05)$ ujemnie skorelowana $\mathrm{z}$ wartością $\mathrm{Na}_{2} \mathrm{CO}_{3} \mathrm{SRC}(\mathrm{r}=-0,433)$. Wymienieni autorzy wyrazili przekonanie o umiarkowanej przydatności metody SRC do określania jakości pieczywa. Podkreślili także niewielkie korelacje wyników metody SRC z parametrami tradycyjnej oceny wartości wypiekowej mąk pszennych. Takie wyniki uwarunkowane zostały najprawdopodobniej różnorodnością użytych surowców (22 próbki mąk pszennych, zarówno handlowych, jak i pochodzących z przemiału laboratoryjnego ziarna pszenicy różnych odmian, z 3 lat uprawy). Xiao i wsp. [26] wykazali natomiast wysokie korelacje $\mathrm{z}$ wieloma parametrami oceny jakości ziarna ozimej pszenicy twardej i mąki z tego ziarna, pomimo że badane odmiany różniły się istotnie pod względem poszczególnych wskaźników testu SRC (Wa SRC - 54,4 $72,1 \%, \mathrm{Na}_{2} \mathrm{CO}_{3} \mathrm{SRC}-64,9 \div 94,0 \%$, Suc SRC $-88,1 \div 142,1 \%$ i LA SRC $-78,3 \div$ $166,8 \%$ ). Najwyższe korelacje autorzy obliczyli pomiędzy LA SRC a objętością bochenka $(\mathrm{r}=0,83, \mathrm{p}<0,0001)$, Wa SRC $\mathrm{z}$ indeksem twardości $(\mathrm{r}=0,68, \mathrm{p}<0,0001)$ oraz LA SRC z zawartością białka $(\mathrm{r}=0,66, \mathrm{p}<0,0001)$. Wydaje się więc, że metoda SRC nie zastąpi uznanych już metod oceny jakości mąk przeznaczonych na cele piekarskie, ale może być stosowana jako dodatkowe źródło informacji, zwłaszcza w sytuacjach, gdy obserwowane są problemy technologiczne. 
Moiraghi i wsp. [20] określili jakość mąk pszennych używanych do produkcji ciast biszkoptowych. Wskazali na możliwość wykorzystania wyników metody SRC do podziału mąk na grupy o różnej charakterystyce, a tym samym o różnych wynikach wypiekowych. Ilość skrobi uszkodzonej (wskazywana przez $\mathrm{Na}_{2} \mathrm{CO}_{3} \mathrm{SRC}$ ) negatywnie wpływała na jakość biszkoptu, natomiast zawartość pentozanów (Suc SRC) - pozytywnie, a jakość białek (LA SCR) nie miała znaczenia. Zdaniem autorów istotne ujemne korelacje $\mathrm{w}$ zakresie $-0,33 \div-0,48(\mathrm{p}<0,05)$ pomiędzy objętością biszkoptów a parametrami SRC są potwierdzeniem, że odpowiednim surowcem do produkcji babek biszkoptowych mogą być frakcje mąk o mniejszych rozmiarach cząstek, niższej wodochłonności i wyższej temperaturze kleikowania. Z kolei Nakamura i wsp. [21] nie zaobserwowali wpływu zawartości pentozanów (Suc SRC) na delikatność biszkoptów, stwierdzili natomiast, że ich zawartość determinowała parametry charakterystyki kleikowania i objętość uzyskiwanego ciasta $(\mathrm{r}=0,69, \mathrm{p}<0,001)$.

Fajardo i Ross [8] zastosowali m.in. metodę SRC do oceny jakości mąki używanej do produkcji naleśników. Nie odnotowali znaczącego wpływu $\mathrm{Na}_{2} \mathrm{CO}_{3} \mathrm{SRC}$ i LA SRC na jakość uzyskanych wyrobów, natomiast Wa SRC oraz Suc SRC były istotnie skorelowane z płynnością ciasta naleśnikowego (odpowiednio: $r=-0,53, r=-0,69$, $\mathrm{p}<0,01$ ), $\mathrm{z}$ ich grubością (odpowiednio: $\mathrm{r}=0,63, \mathrm{r}=0,86, \mathrm{p}<0,01$ ) i średnicą (odpowiednio: $r=-0,69, r=-0,79, p<0,01)$. Autorzy zasugerowali, że cechy naleśników w głównej mierze determinowane są ilością, a nie jakością białek glutenowych.

Metoda SRC została zastosowana także do badania właściwości mąki pszennej poddanej obróbce termicznej. Wartości uzyskiwane dla wszystkich roztworów podlegały różnym zmianom wraz $\mathrm{z}$ przebiegiem procesu prowadzonego $\mathrm{w}$ temp. $150{ }^{\circ} \mathrm{C}$. Wartości $\mathrm{Na}_{2} \mathrm{CO}_{3}$ SRC i LA SRC wzrosły po 5 min obróbki cieplnej, po czym dalsze ogrzewanie nie powodowało istotnych zmian wartości tych parametrów, co wskazywało na ograniczony wpływ obróbki termicznej na pęcznienie uszkodzonych granulek skrobiowych. Poziom Wa SRC zależał natomiast od temperatury obróbki termicznej ulegał niewielkim zmianom przy obróbce w temp. 110 i $130^{\circ} \mathrm{C}$, podczas gdy zastosowanie temp. $190^{\circ} \mathrm{C}$ powodowało bardzo duży i szybki wzrost tego parametru [16].

Hrušková i wsp. [12] badali metodą SRC jakość mieszanek mąk pszennych z domieszką mąki konopnej i z miłki abisyńskiej. Poziomy poszczególnych wskaźników SRC zależały od jakości mąki bazowej oraz od rodzaju i poziomu zastosowanego dodatku. Stwierdzono istotne ujemne korelacje $(\mathrm{p}<0,05)$ pomiędzy wartością Suc SRC a ogólną zawartością błonnika pokarmowego $(\mathrm{r}=-0,69)$, jego frakcją rozpuszczalną $(\mathrm{r}=-0,67)$ i frakcją nierozpuszczalną $(\mathrm{r}=-0,67)$.

Metodę SRC stosowano także do oceny jakości zbóż innych niż pszenica i uzyskiwanych z nich mąk. Drakos i wsp. [4] zastosowali SRC do oceny mąk jęczmiennych i żytnich otrzymanych w młynie strumieniowym. Zaobserwowali, że frakcje mąk jęczmiennych o rozmiarach cząstek $31 \div 43 \mu \mathrm{m}$ charakteryzowały się statystycznie 
istotnie wyższymi wskaźnikami SRC niż te o większym rozmiarze $(182 \mu \mathrm{m})$. Ponadto frakcje mąki żytniej o rozmiarach cząstek $36 \div 55 \mu \mathrm{m}$ i o większej zawartości arabinoksylanów cechowały się niższymi wartościami Suc SRC $(91,4 \div 95,9 \%)$ niż mąka jęczmienna $(137,9 \div 140,5 \%)$.

Aprodu i Banu [2] ocenili metodą SRC jakość ziarna pszenicy, żyta, pszenżyta, jęczmienia i owsa oraz mąk uzyskanych z tych ziaren i dowiedli, że właściwości SRC mogą być uzależnione od rodzaju przemiału zastosowanego do rozdrabniania ziaren, rozkładu wielkości cząstek i składu chemicznego. Autorzy doszli do wniosku, że duże rozbieżności pod względem wartości Wa SRC i Suc SRC wynikają z różnic w strukturze bielma oraz twardości ziarna.

\section{Podsumowanie}

Metoda SRC, podczas jednego relatywnie prostego badania, umożliwia zgromadzenie informacji na temat jakości ziarna lub mąki pszennej i innych zbóż w zakresie kluczowych jej składników: białek glutenowych, skrobi uszkodzonej i pentozanów. Jest powszechnie stosowana w USA do oceny jakości mąk pszennych uzyskanych z przemiału rodzimych odmian pszenicy miękkiej, przeznaczonych do produkcji wyrobów ciastkarskich. Jej pozycja na przestrzeni lat ugruntowała się i zaowocowała wdrożeniem aparatury automatycznej oraz półautomatycznej, co ułatwia wykonanie oznaczenia i zwiększa powtarzalność oraz odtwarzalność uzyskiwanych wyników. Zastosowanie SRC do różnych celów, w poszczególnych rejonach świata, było przedmiotem wielu badań i wskazuje na duży potencjał tej metody. W każdym przypadku konieczna jest jednak odpowiednia walidacja oraz szczegółowa analiza uzyskiwanych wyników na wszystkich etapach łańcucha produkcji - od uprawy, przez przemiał, aż do zakładów przetwarzających mąkę.

\section{Literatura}

[1] Achremowicz B., Berski W., Gambuś H.: Wykorzystanie metody SRC (Solvent Retention Capacity) do oceny jakości technologicznej mąk pszennych. Żywność. Nauka. Technologia. Jakość, 2010, 6 (73), 34-45.

[2] Aprodu I., Banu I.: Milling, functional and thermo-mechanical properties of wheat, rye, triticale, barley and oat. J. Cereal Sci., 2017, 77, 42-48.

[3] Bettge A., Morris C., DeMacon V., Kidwell K.: Adaptation of AACC Method 56-11, SRC, for use as an early generation selection tool for cultivar development. Cereal Chem., 2002, 79 (5), 670-674.

[4] Drakos A., Kyriakakis G., Evageliou V., Protonotariou S., Mandala I., Ritzoulis Ch.: Influence of jet milling and particle size on the composition, physicochemical and mechanical properties of barley and rye flours. Food Chem., 2017, 215, 326-332.

[5] Dubat A., Berra M., Baik B.: Collaborative study report: Automated measurement of wheat flour Solvent Retention Capacity with the Chopin-SRC Instrument (AACC Approved Method 56-15.01). Cereal Foods World, 2019, 64 (3). DOI: 10.1094/CFW-64-3-0033. 
[6] Duyvejonck A., Lagrain B., Pareyt B., Courtin Ch., Delcour J.: Relative contribution of wheat flour constituents to Solvent Retention Capacity profiles of European wheats. J. Cereal Sci., 2011, 53, 312-318.

[7] Dziki D., Różyło R., Laskowski J.: Przemiał pszenicy i wpływ twardości ziarna na ten proces. Acta Agrophysica, 2011, 18 (1), 33-43.

[8] Fajardo C., Ross A.: Exploring relationships between pancake quality and grain and flour functionality in soft wheats. Cereal Chem., 2012, 83 (5), 465-471.

[9] Gaines C.S.: Collaborative study of methods for solvent retention capacity profiles (AACC method 56-11). Cereal Foods World, 2000, 45, 303-306.

[10] Guzman C., Posadas-Romano G., Hernandez-Espinosa N., Moralez-Dorantes A., Pena R.: A new standard water absorption criteria based on SRC to determine dough mixing properties, viscoelasticity and bread-making quality. J. Cereal Sci., 2015, 66, 59-65.

[11] Haynes L.C., Bettge A.D., Slade L.: Soft wheat and flour products method review SRC equation correction. Cereal Food World, 2009, 54, 174-175.

[12] Hrušková M., Švec I., Jurinová I.: Composite flours-characteristics of wheat/hemp and wheat/teff models. Food Nutr. Sci., 2012, 3, 1484-1490.

[13] Jankiewicz M.: Układ białkowy pszenicy - chemia i technologia. Przegl. Zboż. Młyn., 2009, 11, $2-4$.

[14] Jurga R.: Charakterystyka jakościowa i zasady produkcji mąk pszennych o specjalnym przeznaczeniu. Przegl. Zboż. Młyn., 2008, 3, 38-40.

[15] Kaur A., Singh N., Kaur S., Ahlawat A., Singh A.: Relationships of flour SRC, secondary structure and rheological properties with the cookie making characteristics of wheat cultivars. Food Chem., 2014, 158, 48-55.

[16] Keppler S., Bakalis S., Leadley C., Sahi S., Fryer P.: Evaluation of dry heat treatment of soft wheat flour for the production of high ratio cake. Food Res. Int., 2018, 107, 360-370.

[17] Kweon M., Slade L., Levine H.: Development of a benchtop baking method for chemically leavened crackers II. Validation of the method. Cereal Chem., 2011, 88 (1), 25-30.

[18] Kweon M., Slade L., Levine H.: Solvent Retention Capacity (SRC) testing of wheat flour: Principles and value in predicting flour functionality in different wheat-based food processes and in wheat breeding - a review. Cereal Chem., 2011, 88 (6), 537-552.

[19] Kweon M., Slade L., Levine H., Gannon D.: Cookie- versus cracker-baking - what's the difference? Flour functionality requirements explored by SRC and alveography. Crit. Rev. Food Sci. Nutr., 2014, 54 (1), 115-138.

[20] Moiraghi M., de la Hera E., Perez G., Gómez M.: Effect of wheat flour characteristics on sponge cake quality. J. Sci. Food Agric., 2013, 93 (3), 542-549.

[21] Nakamura K., Taniguchi Y., Taira M., Ito H.: Investigation of soft wheat flour quality factors associated with sponge cake sensory tenderness. Cereal Chem., 2012, 89 (2), 79-83.

[22] Obuchowski W., Gutsche M., Makowska A.: Czynniki kształtujące cechy jakościowe mąki przeznaczonej do produkcji wafli. Żywność. Nauka. Technologia. Jakość, 2013, 4 (89), 170-183.

[23] AACC International: Approved Methods of Analysis. 11th ed. Method 56-11.02. Solvent Retention Capacity Profile. American Association of Cereal Chemistry International, St. Paul, Minnesota, USA.

[24] Steffolani M., Perez G., Ribotta P., Leon A.: Relationship between variety classification and breadmaking quality in Argentine wheats. Int. J. Agric. Res., 2007, 2, 33-42.

[25] Švec I., Hrušková M., Karas J., Hofmanová T.: Solvent Retention Capacity for different wheats and flours evaluation. Czech J. Food Sci., 2012, 30 (5), 429-437.

[26] Xiao Z., Park S., Chung O., Caley M., Seib P.: SRC values in relation to hard winter wheat and flour properties and straight-dough breadmaking quality. Cereal Chem., 2006, 83 (5), 465-471. 


\title{
APPLYING SRC METHOD (SOLVENT RETENTION CAPACITY) TO DETERMINE TECHNOLOGICAL SUITABILITY OF WHEAT FLOUR
}

\author{
$\mathrm{S} u \mathrm{~mm}$ a r y
}

The objective of the research study was to present summary information about the SRC method (Solvent Retention Capacity), including its history, available equipment variants, principles of proceeding when carrying out determination and possible options for applications.

The SRC method was developed in the mid- $20^{\text {th }}$ century to assess the quality of flour from soft wheat native to North America. In the $21^{\text {st }}$ century there were published reports presenting data on the usefulness and the potentially wide range of applications of the SRC method when assessing the quality of flour from the standard European common wheat (Triticum aestivum) and of flours obtained from other cereals, such as barley, oats, triticale and rye. The SRC method is a solvation test based on the assessment of swelling capacity of flour components in the medium of selected solvents. Using 3 solvents instead of only one (diluted aqueous sodium carbonate solution, concentrated aqueous sucrose solution and diluted aqueous lactic acid solution) plus water is crucial when assessing the applicability of flour in individual technological processes. When using the affinity between those solvents and the main functional polymers of wheat flour, which are gluten proteins, damaged starch and pentosans, it is possible to determine their effect on the flour properties and on the quality of final products in the bakery and confectionary technology. The SRC method makes it possible to assess the properties of flour, to select wheat varieties or wheat growing methods, which is vital in the milling industry and production plants, where wheat flour is a basic raw material.

Key words: Solvent Retention Capacity (SRC), soft wheat, wheat flour, wafer flour, technological properties 